\title{
DETERMINANT OF POVERTY LEVEL IN WEST KUTAI REGENCY
}

\author{
Oleh: \\ Emanuel Akin \\ Mahasiswa Pascasarjana Universitas Mulawarman \\ E-mail/No.Hp: noel_kin@yahoo.co.id
}

\begin{abstract}
This research is Library Research by using secondary data obtained and seeks to determine and analyze the factors that affect poverty in West Kutai regency, the analysis tool is use Path Analysis. Conclusion of the research results are as follows: (1) Economic Growth, Private Investment Growth (PMA), Labor, and the Growth of Government expenditure jointly direct and significant effect on the Human Development Index (HDI) in West Kutai regency, (2) Workforce dominant influence on the Human Development Index (HDI) in West Kutai regency, (3) Economic Growth, Private Investment Growth (PMA), Labor, and Output Growth Government jointly direct and significant effect on the amount of Poor Population in West Kutai regency, (4) Workforce dominant influence on the amount of Poor People in West Kutai regency, (5) Economic Growth, Private Investment Growth (PMA), Labor, and the Growth of Government influence indirectly through the Human Development Index (HDI) of the total poor population in West Kutai.
\end{abstract}

Keywords: Determinant of Poverty.

\begin{abstract}
Abstrak
Penelitian ini adalah penelitian Perpustakaan dengan mempergunakan data sekunder memperoleh dan mencari untuk menentukan dan meneliti faktor pengaruh itu kemiskinan di Barat Kutai kabupaten, alat analisa adalah Analisa Lintang penggunaan. Kesimpulan dari hasil penelitian adalah sebagai berikut: (1) Kemajuan Ekonomi, Perkembangan Investasi pribadi (PMA), Bekerja keras, dan Perkembangan dari pembelanjaan Pemerintah bersama-sama arahkan dan akibat berpengaruh nyata pada Pembangunan Manusia Indexing (HDI) di Barat Kutai kabupaten, (2) Pengaruh dominan kekuatan pekerja pada Pembangunan Manusia Indexing (HDI) di Barat Kutai kabupaten, (3 ) Kemajuan Ekonomi, Perkembangan Investasi pribadi (PMA), Bekerja keras, dan Pemerintah Perkembangan Keluaran bersama-sama arahkan dan akibat berpengaruh nyata pada sejumlah Populasi Lemah di Barat Kutai kabupaten, (4) pengaruh dominan Kekuatan Pekerja pada sejumlah Orang-orang Lemah di Barat Kutai kabupaten, (5 ) Kemajuan Ekonomi, Perkembangan Investasi pribadi (PMA), Bekerja keras, dan Perkembangan dari pengaruh Pemerintah secara tidak langsung melalui Pembangunan Manusia Indexing (HDI) dari populasi lemah penjumlahan di Kutai Barat.
\end{abstract}

Kata Kunci: Faktor penentu dari Kemiskinan. 


\section{PENDAHULUAN}

Tujuan akhir dari pembangunan adalah terwujudnya kesejahteraan masyarakat secara berkelanjutan dari berbagai aspek, namun seringkali pembangunan daerah termasuk di Kabupaten Kutai Barat mengalami berbagai tantangan dalam mewujudkan hal tersebut. Permasalahan yang seringkali muncul dalam pembangunan di berbagai daerah adalah masalah kemiskinan dan setiap daerah akan selalu berusaha untuk mengatasi masalah tersebut. Kecenderungan terus meningkatnya Indeks Pembangunan Manusia (IPM) di Kabupaten Kutai Barat sepanjang tahun 2002-2011 tidak disertai dengan menurunnya pertumbuhan penduduk miskin secara konsisten.

Pertumbuhan penduduk miskin di Kabupaten Kutai Barat sepanjang tahun 2002-2011 mengalami pergerakan yang fluktuatif, tahun 2003-2006 jumlah penduduk miskin di Kabupaten Kutai Barat menunjukkan pertumbuhan yang positif yaitu tahun 2003 sebesar 5,32 persen, tahun 2004 sebesar 0,50 persen, tahun 2005 sebesar 1,00 persen dan tahun 2006 sebesar 13,93 persen. Sedangkan pada tahun 2007-2009 jumlah penduduk miskin di Kabupaten
Kutai Barat menunjukkan pertumbuhan yang negative yaitu pada tahun 2007 sebesar -6,11 persen, tahun 2008 sebesar -22,33 persen dan tahun 2009 sebesar $-14,37$ persen. Kemudian jumlah penduduk miskin di Kabupaten Kutai Barat kembali mengalami pertumbuhan yang positif pada tahun 2010 sebesar 15,38 persen dan pada tahun 2011 sebesar 1,02 persen.

Berdasarkan uraian tersebut diatas, maka untuk mengetahui faktorfaktor yang mempengaruhi kemiskinan di Kabupaten Kutai Barat penulis tertarik untuk mengadakan penelitian dengan judul "Determinan Tingkat Kemiskinan Penduduk Kabupaten Kutai Barat.

\section{METODE PENELITIAN}

Persepsi tentang objek yang diamati dalam penelitian ini dan menghindari terjadinya perbedaan penafsiran, maka penulis memberi batasan definisi operasional yang Pertama adalah kemiskinan adalah ketidakmampuan dari sisi ekonomi untuk memenuhi kebutuhan dasar makanan dan bukan makanan yang dinyatakan dalam jumlah penduduk miskin. Kedua,penduduk Miskin adalah penduduk Kabupaten Kutai Barat yang 
memiliki rata-rata pengeluaran per kapita per bulan dibawah garis kemiskinan. Ketiga Indeks Pembangunan Manusia adalah angka indeks komposit yang sudah dihitung oleh BPS berdasarkan formulasi yang ditetapkan UNDP. Keempat Pertumbuhan Ekonomi adalah pertumbuhan PDRB Kabupaten Kutai Barat. Kelima, Investasi Swasta adalah realisasi Penanaman Modal Asing (PMA) di Kabupaten Kutai Barat. Keenam Tenaga Kerja adalah jumlah penduduk yang berumur 15 tahun keatas sebagai angkatan kerja yang terserap pada sector ekonomi di Kabupaten Kutai Barat. Ketujuh Pengeluaran pemerintah adalah besaran nilai realisasi APBD Kabupaten Kutai Barat setiap tahun.

\section{PEMBAHASAN}

Berdasarkan data hasil penelitian dan untuk menjawab rumusan masalah Persamaan Sub Struktur pertama adalah $\mathrm{Y}=\rho \mathrm{YX} 1+\rho \mathrm{YX} 2+\rho \mathrm{YX} 3+\rho \mathrm{YX} 4+$ e1

Dimana:

$$
\begin{aligned}
\mathrm{Y}= & \text { Indeks Pembangunan Manusia } \\
& (\mathrm{IPM}), \\
\rho= & \text { Koefisien Jalur, } \\
\mathrm{X} 1= & \text { Pertumbuhan Ekonomi, }
\end{aligned}
$$

Penelitian dilaksanakan di Kabupaten Kutai Barat Provinsi Kalimantan Timur. Data yang digunakan adalah data sekunder Time Series (Runtut Waktu) selama periode tahun 2002 - 2011. Penelitian difokuskan pada pengaruh variable eksogen Pertumbuhan Ekonomi, Pertumbuhan Investasi Swasta (PMA), Tenaga Kerja, dan Pertumbuhaan Pengeluaran Pemerintah terhadap variabel endogen Kemiskinan, baik pengaruh secara langsung maupun pengaruh secara tidak langsung melalui Indeks Pembangunan Manusia (IPM) sebagai variabel antara (intervening variable). Teknik pengumpulan data dilakukan dengan cara observasi dan dokumentasi (Library Research).

yang telah ditetapkan, maka digunakan Analisis Jalur (Path Analysis) dengan persamaanstruktural

$\mathrm{X} 2=$ Pertumbuhan Investasi Swasta (PMA), $\mathrm{X} 3=$ Tenaga, Kerja ,

$\mathrm{X} 4=$ Pertumbuhan Pengeluaran Pemerintah, $\mathrm{e}=$ Residue

Persamaan Sub Struktur kedua adalah 


$$
\begin{aligned}
Z= & \rho Z X 1+\rho Z X 2+\rho Z X 3+\rho Z X 4+ \\
& \rho Z Y+e 1 \ldots \ldots \ldots \ldots \ldots \ldots \ldots \ldots \ldots \ldots(2)
\end{aligned}
$$

Dimana:

$\mathrm{Z}=$ Kemiskinan

$\mathrm{Y}=$ Indeks Pembangunan Manusia (IPM),

$\rho=$ Koefisien Jalur,

Persamaan Sub Struktur yang pertama adalah pengaruh Secara

Gabungan (Simultan). Pengaruh

lxiablelxile eksogen Pertumbuhan

Ekonomi, Pertumbuhan Investasi

Swasta (PMA), Tenaga Kerja, dan

\author{
$\mathrm{X} 1=$ Pertumbuhan Ekonomi, \\ $\mathrm{X} 2=$ Pertumbuhan Investasi Swasta \\ (PMA), \\ $\mathrm{X} 3=$ Tenaga Kerja, \\ X4= Pertumbuhan Pengeluaran \\ Pemerintah, \\ $\mathrm{e}=$ Residue
}

Pertumbuhan Pengeluaran Pemerintah terhadap Indeks Pembangunan Manusia (IPM) dapat dilihat pada nilai $\mathrm{R}$ square pada lxiable Model Summary berikut ini :

Tabel. 1 Model Regresi: Koefisien Determinasi dan Uji F

\begin{tabular}{|c|c|c|c|c|c|c|c|c|c|c|}
\hline \multirow[b]{2}{*}{$\begin{array}{l}\text { Mod } \\
\text { el }\end{array}$} & \multirow[b]{2}{*}{$\mathrm{R}$} & \multirow[b]{2}{*}{$\begin{array}{c}\mathrm{R} \\
\text { Square }\end{array}$} & \multirow[b]{2}{*}{$\begin{array}{c}\text { Adjusted R } \\
\text { Square }\end{array}$} & \multirow{2}{*}{$\begin{array}{l}\text { Std. Error } \\
\text { of the } \\
\text { Estimate }\end{array}$} & \multicolumn{5}{|c|}{ Change Statistics } & \multirow[b]{2}{*}{$\begin{array}{l}\text { Durbin- } \\
\text { Watson }\end{array}$} \\
\hline & & & & & $\begin{array}{l}\text { R Square } \\
\text { Change }\end{array}$ & $\begin{array}{c}\mathrm{F} \\
\text { Change }\end{array}$ & df1 & df2 & $\begin{array}{l}\text { Sig. F } \\
\text { Change }\end{array}$ & \\
\hline 1 & $.981^{\mathrm{a}}$ & .962 & .931 & .55774 & .962 & 31.482 & 4 & 5 & .001 & 1.128 \\
\hline
\end{tabular}

Model Summary ${ }^{b}$

a. Predictors: (Constant), pert. peng pemerintah, tenaga kerja, pertumbuhan pma, pertumbuhan ekonomi

b. Dependent Variable: ipm

Besarnya nilai $R$ square $\left(R^{2}\right)$ adalah 0,962 dengan signifikansi 0,001. Angka tersebut mempunyai makna bahwa besarnya pengaruh variabel eksogen Pertumbuhan Ekonomi, Pertumbuhan Investasi Swasta (PMA), Tenaga Kerja, dan Pertumbuhan Pengeluaran Pemerintah terhadap Indeks Pembangunan Manusia (IPM) secara gabungan (simultan) adalah sebesar 96,2 persen, sedangkan sisanya sebesar 3,80 persen dipengaruhi oleh faktor lain di luar model penelitian. Hasil penelitian sesuai dengan hipotesis karena signifikansi $0,001<0,05(\alpha=5$ $\%$ ), hal ini berarti secara bersama-sama variabel eksogen Pertumbuhan Ekonomi, Pertumbuhan Investasi Swasta (PMA), Tenaga Kerja, dan Pertumbuhan Pengeluaran Pemerintah berpengaruh secara langsung dan signifikan terhadap Indeks Pembangunan Manusia (IPM) di Kabupaten Kutai Barat. 
Pengaruh Secara Parsial Besarnya pengaruh variabel eksogen Pertumbuhan Ekonomi, Pertumbuhan Investasi Swasta, Tenaga Kerja, dan Pertumbuhan Pengeluaran Pemerintah terhadap Indeks Pembangunan Manusia

Tabel 2. Koefisien Regresi dan Uji Secara Pasrtial

Coefficients $^{\mathrm{a}}$

\begin{tabular}{|c|c|c|c|c|c|c|c|c|c|c|c|c|}
\hline \multirow[b]{2}{*}{ Model } & \multicolumn{2}{|c|}{$\begin{array}{l}\text { Unstandardized } \\
\text { Coefficients }\end{array}$} & \multirow{2}{*}{$\begin{array}{c}\begin{array}{c}\text { Standardized } \\
\text { Coefficients }\end{array} \\
\text { Beta } \\
\end{array}$} & \multirow[b]{2}{*}{$\mathrm{T}$} & \multirow[b]{2}{*}{ Sig. } & \multicolumn{2}{|c|}{$\begin{array}{c}95 \% \\
\text { Confidence } \\
\text { Interval for B }\end{array}$} & \multicolumn{3}{|c|}{ Correlations } & \multicolumn{2}{|c|}{$\begin{array}{l}\text { Collinearity } \\
\text { Statistics }\end{array}$} \\
\hline & B & $\begin{array}{l}\text { Std. } \\
\text { Error }\end{array}$ & & & & $\begin{array}{l}\text { Lower } \\
\text { Bound }\end{array}$ & $\begin{array}{l}\text { Upper } \\
\text { Bound }\end{array}$ & $\begin{array}{l}\text { Zero- } \\
\text { order }\end{array}$ & Partial & Part & Tolerance & VIF \\
\hline 1 (Constant) & 54.506 & 3.122 & & 17.456 & .000 & 46.479 & 62.532 & & & & & \\
\hline $\begin{array}{l}\text { pertumbuhan } \\
\text { ekonomi }\end{array}$ & -.327 & .110 & -.354 & -2.977 & .031 & -.609 & -.045 & -.722 & -.800 & -.260 & .541 & 1.847 \\
\hline pertumbuhan pma & .027 & .006 & .474 & 4.272 & .008 & .011 & .042 & -.058 & .886 & .373 & .621 & 1.609 \\
\hline tenaga kerja & .000 & .000 & .878 & 7.274 & .001 & .000 & .000 & .874 & .956 & .636 & .525 & 1.907 \\
\hline $\begin{array}{l}\text { pert. peng } \\
\text { pemerintah }\end{array}$ & .015 & .006 & .263 & 2.440 & .059 & .000 & .031 & -.127 & .737 & .213 & .656 & 1.524 \\
\hline
\end{tabular}

a. Dependent Variable: ipm

Hubungan antara variabel Pertumbuhan Ekonomi dengan IPM Nilai t penelitian pada tabel Coefficient adalah sebesar -2.977 dengan signifikansi 0,031 .

Nilai t tabel pada taraf signifikansi $0,05(\alpha=5 \%)$ dan Degree of Freedom $(\mathrm{DF}) /$ Derajat Kebebasan $(\mathrm{DK})=\mathrm{n}-2$, atau 10-2 = 8 diperoleh angka $\mathrm{t}$ tabel sebesar 2,306.Hasil SPSS menunjukkan angka $\mathrm{t}$ penelitian sebesar $-2.977>\mathrm{t}$ tabel sebesar 2,306. Hubungan antara variabel Pertumbuhan Investasi Swasta (PMA) dengan IPM. Nilai t tabel pada taraf signifikansi $0,05(\alpha=5 \%)$ dan Degree of Freedom (DF)/Derajat
(IPM) secara sendiri-sendiri (parsial) dapat dilihat dari nilai Beta atau Standardized Coefficient, sedangkan untuk pengujian hipotesisnya digunakan nilai t. 
$(\alpha=10 \%)$ dan Degree of Freedom

$(\mathrm{DF}) /$ Derajat Kebebasan $(\mathrm{DK})=\mathrm{n}-2$, atau 10-2 $=8$ diperoleh angka $t$ tabel sebesar 1,860. Hasil SPSS menunjukkan angka t penelitian sebesar 2,440 > t tabel sebesar 1,860. Melihat Kelayakan Model Regresi mengetahui Tabel 3. Anova

\begin{tabular}{lllllll}
\hline Model & Sum of Squares & Df & Mean Square & $F$ & Sig. \\
\hline 1 & Regression & 39.173 & 4 & 9.793 & 31.482 & $.001^{\mathrm{a}}$ \\
\cline { 2 - 7 } & Residual & 1.555 & 5 & .311 & & \\
\cline { 2 - 6 } & Total & 40.729 & 9 & & & \\
\hline
\end{tabular}

a. Predictors: (Constant), pert. peng pemerintah, tenaga kerja, pertumbuhan pma, pertumbuhan ekonomi

b. Dependent Variable: ipm

Hasil SPSS menunjukkan angka signifikansi/probabilitas sebesar $0,001<$ 0,05; dengan demikian maka model regresi yang dibuat sudah layak/benar.

\section{Menguji kelayakan Koefisien} Regresi/Bobot Beta, Jika dilihat pada tabel coefficients, maka signifikansi koefisien regresi untuk masing masing variabel eksogen adalah :Variabel Pertumbuhan Ekonomi sebesar 0,031, Variabel, Pertumbuhan Investasi Swasta (PMA) sebesar 0,008, Variabel Tenaga, Kerja sebesar 0,001, Variabel Pertumbuhan Pengeluaran Pemerintah sebesar 0,059. Kesimpulannya adalah tiga variabel eksogen mempunyai koefisien regresi yang, signifikan pada taraf kepercayaan $0,05(\alpha=5 \%)$ yaitu variabel Pertumbuhan Ekonomi dengan apakah model regresi sudah benar, maka dilakukan pengujian model yang sudah dibuat.

Pengujian model dapat dilakukan dengan cara menggunakan nilai signifikansi/probabilitas pada tabel

ANOVA berikut ini :

nilai signifikansi sebesar 0,031 , variabel Pertumbuhan Investasi Swasta (PMA) dengan nilai signifikansi sebesar 0,008, dan variabel Tenaga Kerja dengan nilai signifikansi sebesar 0,001 . Sedangkan satu variabel eksogen mempunyai koefisien regresi yang tidak signifikan pada taraf kepercayaan $0,05(\alpha=5 \%)$ yaitu variabel Pertumbuhan Pengeluaran Pemerintah dengan nilai signifikansi sebesar 0,059, namun signifikan pada taraf kepercayaan 0,10 $(\alpha=10 \%)$.

Menguji Autokorelasi adalah Menguji apakah terdapat autokorelasi atau tidak dalam model regresi, ketentuannya ialah : terjadi autokorelasi jika nilai Durbin-Watson $=1<\mathrm{DW}>3$. (Sarwono, 2012 : 91). 
Model Summary

\begin{tabular}{|c|c|c|c|c|c|c|c|c|c|c|}
\hline \multirow[b]{2}{*}{ Model } & \multirow[b]{2}{*}{$\mathrm{R}$} & \multirow[b]{2}{*}{$\begin{array}{c}\mathrm{R} \\
\text { Square }\end{array}$} & \multirow[b]{2}{*}{$\begin{array}{l}\text { Adjusted } \\
\text { R Square }\end{array}$} & \multirow{2}{*}{$\begin{array}{l}\text { Std. Error } \\
\text { of the } \\
\text { Estimate }\end{array}$} & \multicolumn{5}{|c|}{ Change Statistics } & \multirow[b]{2}{*}{$\begin{array}{l}\text { Durbin- } \\
\text { Watson }\end{array}$} \\
\hline & & & & & $\begin{array}{l}\text { R Square } \\
\text { Change }\end{array}$ & $\begin{array}{c}\mathrm{F} \\
\text { Change }\end{array}$ & df1 & df2 & Sig. F Change & \\
\hline$\overline{1}$ & $.981^{a}$ & .962 & .931 & .55774 & .962 & 31.482 & 4 & 5 & .001 & 1.128 \\
\hline
\end{tabular}

a. Predictors: (Constant), Pertumbuhan Pengeluaran Pemerintah, Tenaga Kerja, Pertumbuhan Investasi Swasta (PMA), Pertumbuhan Ekonomi

b. Dependent Variable: IPM

Dari hasil perhitungan diatas diperoleh nilai Durbin-Watson sebesar 1,128 , berarti tidak terjadi autokorelasi dalam model regresi berganda yang dibuat. Keberadaan multikolinieritas dideteksi dengan melakukan uji formal yaitu dengan melihat nilai Tolerance (TOL) dan Variance Inflation Factor (VIF) pada model regresi. Variabel lebih besar dari nilai 10 (Hair et al. 1992) dalam Priyatno (2009 : 156). Dari tabel coefficients diperoleh nilai VIF untuk masing-masing variabel adalah 1.847; 1.609; 1.907; dan 1.524, hasil ini menunjukkan nilai Tolerance (TOL) lebih besar dari 0,10 dan nilai Variance Inflation Factor (VIF) kurang dari 10 sehingga dapat disimpulkan bahwa

Tabel. 5 Koefisien Regresi dan Uji Secara Pasrtial

\section{Coefficients $^{\mathrm{a}}$}

\begin{tabular}{|c|c|c|c|c|c|c|c|c|c|c|c|}
\hline \multirow[b]{2}{*}{ Model } & \multicolumn{2}{|c|}{$\begin{array}{l}\text { Unstandardized } \\
\text { Coefficients }\end{array}$} & \multirow{2}{*}{$\begin{array}{c}\begin{array}{c}\text { Standardized } \\
\text { Coefficients }\end{array} \\
\text { Beta }\end{array}$} & \multirow[b]{2}{*}{$\mathrm{T}$} & \multirow[b]{2}{*}{ Sig. } & \multicolumn{2}{|c|}{$\begin{array}{l}95 \% \text { Confidence } \\
\text { Interval for B }\end{array}$} & \multicolumn{2}{|c|}{ Correlations } & \multicolumn{2}{|c|}{$\begin{array}{c}\text { Collinearity } \\
\text { Statistics }\end{array}$} \\
\hline & B & $\begin{array}{l}\text { Std. } \\
\text { Error }\end{array}$ & & & & $\begin{array}{l}\text { Lower } \\
\text { Bound }\end{array}$ & $\begin{array}{l}\text { Upper } \\
\text { Bound }\end{array}$ & $\begin{array}{l}\text { Zero- Part } \\
\text { order ial }\end{array}$ & Part & $\begin{array}{c}\text { Tole } \\
\text { ranc } \\
\mathrm{e}\end{array}$ & VIF \\
\hline 1 (Constant) & 149.863 & 16.652 & & 9.000 & .001 & 103.630 & 196.096 & & & & \\
\hline $\begin{array}{l}\text { pertumbuhan } \\
\text { ekonomi }\end{array}$ & -1.118 & .124 & -1.199 & -9.021 & .001 & -1.462 & -.774 & . 263. & -.530 & .195 & 5.120 \\
\hline $\begin{array}{l}\text { pertumbuhan } \\
\text { pma }\end{array}$ & .052 & .009 & .915 & 5.699 & .005 & .026 & .077 & .269 .944 & .335 & .134 & 7.485 \\
\hline tenaga kerja & .000 & .000 & .631 & 2.287 & .084 & .000 & .000 & -.833 .753 & .134 & .045 & 22.084 \\
\hline $\begin{array}{l}\text { pert. peng } \\
\text { pemerintah }\end{array}$ & .043 & .006 & .736 & 6.862 & .002 & .026 & .061 & .150 .960 & .403 & .299 & 3.340 \\
\hline Ipm & -2.021 & .303 & -2.004 & -6.670 & .003 & -2.862 & -1.180 & $\begin{array}{l}-.734 .958 \\
\end{array}$ & -.392 & .038 & 26.186 \\
\hline
\end{tabular}

\section{a. Dependent Variable:}

persentase pddk miskin

yang menyebabkan multikolinieritas dapat dilihat dari nilai Tolerance (TOL) yang lebih kecil dari 0,10 atau nilai Variance Inflation Factor (VIF) yang tidak terjadi Multikolinieritas dalam model persamaan regresi.

Kesimpulannya ialah model regresi yang ada sudah memenuhi 
semua persyaratan, dengan demikian model regresi linier berganda dalam analisis ini sudah layak/benar. Persamaan Sub Struktur kedua adalah Pengaruh Secara Gabungan (Simultan). Pengaruh variabel eksogen
Pertumbuhan Ekonomi, Pertumbuhan Investasi Swasta, Tenaga Kerja, dan Pertumbuhan Pengeluaran Pemerintah terhadap variabel endogen Kemiskinan dapat dilihat pada nilai $\mathrm{R}$ square pada tabel Model Summary berikut ini :

Tabel 6. R Square

Model Summary

\begin{tabular}{|c|c|c|c|c|c|c|c|c|c|c|}
\hline \multirow{2}{*}{$\begin{array}{l}\text { M } \\
\text { od } \\
\text { el }\end{array}$} & \multirow[b]{2}{*}{$\mathrm{R}$} & \multirow[b]{2}{*}{$\begin{array}{c}\mathrm{R} \\
\text { Square }\end{array}$} & \multirow[b]{2}{*}{$\begin{array}{l}\text { Adjusted } \\
\text { R Square }\end{array}$} & \multirow{2}{*}{$\begin{array}{l}\text { Std. Error } \\
\text { of the } \\
\text { Estimate }\end{array}$} & \multicolumn{5}{|c|}{ Change Statistics } & \multirow[b]{2}{*}{$\begin{array}{l}\text { Durbin- } \\
\text { Watson }\end{array}$} \\
\hline & & & & & $\begin{array}{l}\text { R Square } \\
\text { Change }\end{array}$ & $\begin{array}{c}\mathrm{F} \\
\text { Change }\end{array}$ & df1 & $\mathrm{df} 2$ & $\begin{array}{l}\text { Sig. F } \\
\text { Change }\end{array}$ & \\
\hline 1 & $.993^{\mathrm{a}}$ & .986 & .969 & .37792 & .986 & 57.217 & 5 & 4 & .001 & 2.451 \\
\hline
\end{tabular}

b. Dependent Variable: persentase pddk miskin

Besarnya nilai $\mathrm{R}$ square (R2) adalah 0,969 dengan signifikansi 0,001. Angka tersebut mempunyai makna bahwa besarnya pengaruh variabel Pertumbuhan Ekonomi, Pertumbuhan Investasi Swasta (PMA), Tenaga Kerja, Pertumbuhan Pengeluaran Pemerintah dan IPM terhadap Kemiskinan secara gabungan (simultan) adalah sebesar 96,9 persen, sedangkan sisanya sebesar 3,1 persen dipengaruhi oleh faktor lain di luar model penelitian. Hasil penelitian sesuai dengan hipotesis karena signifikansi $0,001<.0,05(\alpha=5$ $\%)$, hal ini berarti secara bersama-sama variabel Pertumbuhan Ekonomi, Pertumbuhan Investasi Swasta (PMA), Tenaga Kerja, dan Pertumbuhan
Pengeluaran Pemerintah berpengaruh secara langsung dan signifikan terhadap Kemiskinan di Kabupaten Kutai Barat.Pengaruh Secara Parsial Besarnya pengaruh variabel Pertumbuhan.

Ekonomi, Pertumbuhan Investasi Swasta (PMA), Tenaga Kerja, dan Pertumbuhan. Pengeluaran Pemerintah terhadap Kemiskinan secara sendirisendiri (parsial) dapat dilihat dari nilai Beta atau Standardized Coefficient, sedangkan untuk pengujian hipotesisnya digunakan nila $t$ Hubungan antara variabel Pertumbuhan Ekonomi dengan Kemiskinan. Nilai $\mathrm{t}$ penelitian pada tabel Coefficient adalah sebesar -1,972 dengan signifikansi 0,106 . Nilai $\mathrm{t}$ tabel pada taraf signifikansi $0,05(\alpha=5 \%)$ 
dan Degree of Freedom (DF)/Derajat Kebebasan $(\mathrm{DK})=\mathrm{n}-3$, atau 10-3 = 7 diperoleh angka t tabel sebesar 2,365. Hubungan antara variabel Pertumbuhan Investasi Swasta (PMA) dengan Kemiskinan. Nilai $\mathrm{t}$ penelitian pada tabel Coefficient adalah sebesar 5,699 dengan signifikansi 0,005 .Nilai $\mathrm{t}$ tabel pada taraf signifikansi $0,05(\alpha=5 \%)$ dan Degree of Freedom (DF)/Derajat Kebebasan $(\mathrm{DK})=\mathrm{n}-3$, atau 10-3 = 7 diperoleh angka t tabel sebesar 2,365.

Hubungan antara variabel Tenaga Kerja dengan Kemiskinan. Nilai $t$ penelitian pada tabel Coefficient adalah sebesar 2,287 dengan signifikansi 0,084. Nilai $t$ tabel pada taraf signifikansi 0,05 ( $\alpha=5 \%)$ dan Degree
DK) $=n-3$, atau 10-3 = 7 diperoleh angka t tabel sebesar 2,365. Hubungan antara variabel Pertumbuhan Pengeluaran Pemerintah dengan Kemiskinan. Nilai $\mathrm{t}$ penelitian pada tabel Coefficient adalah sebesar 6,862 dengan signifikansi 0,002 .Nilai $t$ tabel pada taraf signifikansi $0,05(\alpha=5 \%)$ dan Degree of Freedom (DF)/Derajat Kebebasan $(\mathrm{DK})=\mathrm{n}-3$, atau 10-3 = 7 diperoleh angka t tabel sebesar 2,365. Hubungan antara variabel IPM dengan Kemiskinan. Nilai $\mathrm{t}$ penelitian pada tabel Coefficient adalah sebesar $-6,670$ dengan signifikansi 0,003 . Nilai t tabel pada taraf signifikansi $0,05(\alpha=5 \%)$ dan Degree of Freedom (DF)/Derajat Kebebasan $(\mathrm{DK})=\mathrm{n}-3$, atau 10-3 = 7

Tabel 7. Anova

\begin{tabular}{llrrrrr}
\hline \multirow{2}{*}{ Model } & $\begin{array}{l}\text { Sum of } \\
\text { Squares }\end{array}$ & Df & Mean Square & F & \multicolumn{1}{c}{ Sig. } \\
\hline 1 & Regression & 40.860 & 5 & 8.172 & 57.217 & $.001 \mathrm{a}$ \\
\cline { 2 - 7 } & Residual & .571 & 4 & .143 & & \\
\cline { 2 - 6 } & Total & 41.431 & 9 & & & \\
\hline
\end{tabular}

a. Predictors: (Constant), ipm, pertumbuhan pma, pert. peng pemerintah, pertumbuhan ekonomi, tenaga kerja

b. Dependent Variable: persentase pddk miskin

of Freedom (DF)/Derajat Kebebasan

diperoleh angka t tabel sebesar 2,365

Validitas Hasil Penelitian Sub Struktur

2 adalah Melihat Kelayakan Model

Regresi Untuk mengetahui apakah model regresi sudah benar, maka dilakukan pengujian model yang sudah dibuat. Pengujian model dapat dilakukan dengan cara menggunakan nilai signifikansi/probabilitas pada tabel ANOVA berikut ini Hasil SPSS menunjukkan angka 
signifikansi/probabilitas sebesar $0,001<$ 0,05; dengan demikian maka model regresi yang dibuat sudah layak/benar.

Menguji kelayakan Koefisien Regresi/Bobot Beta Jika dilihat pada tabel coefficients, maka signifikansi koefisien regresi untuk masing-masing variabel eksogen adalah Variabel Pertumbuhan Ekonomi sebesar 0,001, Variabel Pertumbuhan Investasi Swasta (PMA) sebesar 0,005, Variabel Tenaga Kerja sebesar 0,084, Variabel Pertumbuhan Pengeluaran Pemerintah sebesar 0,002, Variabel IPM sebesar 0,003

Kesimpulannya adalah satu variabel eksogen mempunyai signifikansi koefisien regresi yang tidak signifikan pada taraf kepercayaan 0,05 $(\alpha=5 \%)$ yaitu variabel Tenaga Kerja dengan nilai signifikansi sebesar 0,084 . Sedangkan empat variabel eksogen lainnya mempunyai koefisien regresi yang signifikan pada taraf kepercayaan $0,05(\alpha=5 \%)$ yaitu variabel Pertumbuhan Ekonomi dengan nilai signifikansi sebesar 0,001 , Pertumbuhan Investasi Swasta (PMA) dengan nilai signifikansi sebesar 0,005, dan Pertumbuhan Pengeluaran Pemerintah dengan nilai signifikansi sebesar 0,002 dan IPM dengan nilai signifikansi sebesar 0,003. Menguji Autokorelasi adalah Menguji apakah terdapat autokorelasi atau tidak dalam model regresi, ketentuannya ialah : terjadi autokorelasi jika nilai DurbinWatson $=1<$ DW $>3$. (Sarwono, 2012 : 91).

Tabel 8. Uji Durbin Watson

Model Summary ${ }^{b}$

\begin{tabular}{|c|c|c|c|c|c|c|c|c|c|c|}
\hline \multirow[b]{2}{*}{ Model } & \multirow[b]{2}{*}{$\mathrm{R}$} & \multirow[b]{2}{*}{$\begin{array}{c}\mathrm{R} \\
\text { Square }\end{array}$} & \multirow{2}{*}{$\begin{array}{l}\text { Adjusted } \\
\text { R Square }\end{array}$} & \multirow{2}{*}{$\begin{array}{l}\text { Std. Error } \\
\text { of the } \\
\text { Estimate }\end{array}$} & \multicolumn{5}{|c|}{ Change Statistics } & \multirow{2}{*}{$\begin{array}{l}\text { Durbin- } \\
\text { Watson }\end{array}$} \\
\hline & & & & & $\begin{array}{l}\text { R Square } \\
\text { Change }\end{array}$ & $\begin{array}{c}\mathrm{F} \\
\text { Change }\end{array}$ & df1 & $\mathrm{df} 2$ & $\begin{array}{l}\text { Sig. F } \\
\text { Change }\end{array}$ & \\
\hline 1 & .993 & .986 & .969 & .37792 & .986 & 57.217 & & & .001 & 2.451 \\
\hline
\end{tabular}

a. Predictors: (Constant), ipm, pertumbuhan pma, pert. peng pemerintah, pertumbuhan ekonomi, tenaga kerja

b. Dependent Variable: persentase pddk miskin

Dari hasil perhitungan tabel 8 diperoleh nilai Durbin-Watson sebesar 2,451, berarti tidak terjadi autokorelasi dalam model regresi berganda yang dibuat. Menguji Multikolinieritas adalah Mendeteksi keberadaan multikolinieritas dilakukan uji formal yaitu dengan melihat nilai Tolerance 
(TOL) dan Variance Inflation Factor (VIF) pada model regresi. Variabel yang menyebabkan multikolinieritas dapat dilihat dari nilai Tolerance (TOL) yang lebih kecil dari 0,10 atau nilai Variance Inflation Factor (VIF) yang lebih besar dari nilai 10 (Hair et al. 1992) dalam Priyatno (2009 : 156).

Dari output SPSS dalam tabel coefficients menunjukkan nilai VIF masing-masing variabel eksogen yaituVariabel pertumbuhan ekonomi sebesar 5.120, Variabel pertumbuhan PMA sebesar 7.485, Variabel tenaga kerja sebesar 22.084, Variabel pengeluaran pemerintah sebesar 3.340, Variabel IPM sebesar 26.186

\section{PEMBAHASAN}

Dari hasil tersebut terindikasi terjadi multikolinierits pada 2 variabel eksogen yaitu variabel tenaga kerja dan variabel IPM, sedangkan ketiga variabel eksogen lainnya tidak terjadi multikolininieritas karena nilai VIF-nya kurang dari 10.

Pembahasan Hasil penelitian ini menemukan adanya beberapa variabel yang memiliki relevansi yang mendukung hipotesis, kajian empiris dan teori, namun terdapat juga variabel yang hasilnya tidak sesuai atau tidak mendukung hipotesis dan teori yang ada.

Persamaan Struktur IPengaruh Secara Gabungan (Simultan)Besarnya nilai $\mathrm{R}$ square $\left(\mathrm{R}_{2}\right)$ adalah 0,962 dengan signifikansi 0,001. Angka tersebut mempunyai makna bahwa besarnya pengaruh variabel eksogen Pertumbuhan Ekonomi, Pertumbuhan Investasi Swasta (PMA), Tenaga Kerja, dan Pertumbuhan Pengeluaran Pemerintah terhadap Indeks Pembangunan Manusia (IPM) secara gabungan (simultan) adalah sebesar 96,2 persen, sedangkan sisanya sebesar 3,80 persen dipengaruhi oleh faktor lain di luar model penelitian. Hasil penelitian sesuai dengan hipotesis karena signifikansi $0,001<0,05(\alpha=5$ $\%)$, hal ini berarti secara bersama-sama variabel eksogen Pertumbuhan Ekonomi, Pertumbuhan Investasi Swasta (PMA), Tenaga Kerja, dan Pertumbuhan Pengeluaran Pemerintah berpengaruh secara langsung dan signifikan terhadap Indeks Pembangunan Manusia (IPM) di Kabupaten Kutai Barat.

Pengaruh Secara Parsial Besarnya pengaruh variabel eksogen Pertumbuhan Ekonomi, Pertumbuhan Investasi Swasta, Tenaga Kerja, dan 
Pertumbuhan Pengeluaran Pemerintah terhadap Indeks Pembangunan Manusia (IPM) secara sendiri-sendiri (parsial) adalah sebagai berikut :

Hubungan antara variabel Pertumbuhan Ekonomi dengan IPM. Hasil SPSS menunjukkan angka $\mathrm{t}$ penelitian sebesar $-2.977>\mathrm{t}$ tabel sebesar 2,306, artinya secara parsial variabel Pertumbuhan Ekonomi berpengaruh secara langsung dan signifikan terhadap Indeks Pembangunan Manusia (IPM) di Kabupaten Kutai Barat. Besarnya pengaruh variabel Pertumbuhan Ekonomi terhadap Indeks Pembangunan Manusia (IPM) adalah sebesar -0.354 . Pengaruh ini signifikan karena nilai signifikansi/probabilitas hasil perhitungan sebesar $0,031<0,05$.

Hasil penelitian menunjukan bahwa terjadi hubungan yang negative antara keduanya di Kabupaten Kutai Barat. Hubungan yang negative tersebut menunujkan bahwa pertumbuhan ekonomi Kabupaten Kutai Barat belum berkualitas dan terjadinya kesenjangan ekonomi yang semakin lebar. Pertumbuhan Ekonomi tidak dinikmati secara merata tetapi hanya dinikmati kelompok kecil masyarakat.
Hubungan antara variabel Pertumbuhan Investasi Swasta (PMA) dengan IPM. Hasil SPSS menunjukkan angka $\mathrm{t}$ penelitian sebesar 4,272>t tabel sebesar 2,306, artinya secara parsial variabel Pertumbuhan Investasi Swasta (PMA) berpengaruh secara langsung dan signifikan terhadap Indeks Pembangunan Manusia (IPM) di Kabupaten Kutai Barat. Besarnya pengaruh variabel Pertumbuhan Investasi Swasta (PMA) terhadap Indeks Pembangunan Manusia (IPM) adalah sebesar 0,474. Pengaruh ini signifikan karena nilai signifikansi/probabilitas hasil perhitungan sebesar 0,008<0,05.

Hasil penelitian menunjukan bahwa terjadi hubungan yang positif diantara keduanya, hubungan yang positif tersebut disebabkan bahwa modal asing cenderung meningkatkan produktifitas, pendapatan dan pekerjaan yang pada gilirannya mengarah pada upah riil buruh yang semakin tinggi.

Hubungan antara variabel Tenaga Kerja dengan IPM. Hasil SPSS menunjukkan angka t penelitian sebesar 7,193 > t tabel sebesar 2,306, artinya secara parsial variabel Tenaga Kerja berpengaruh secara langsung dan signifikan terhadap Indeks 
Pembangunan Manusia (IPM) di Kabupaten Kutai Barat. Besarnya pengaruh variabel Tenaga Kerja terhadap Indeks Pembangunan Manusia (IPM) sebesar 0,878. Pengaruh ini signifikan karena nilai signifikansi/probabilitas hasil perhitungan sebesar $0,001<0,05$. Hubungan antara variabel Pertumbuhan Pengeluaran Pemerintah dengan IPM

Hasil SPSS menunjukkan angka $t$ penelitian sebesar $2,440>\mathrm{t}$ tabel sebesar 1,860, artinya secara parsial variabel Pertumbuhan Pengeluaran Pemerintah berpengaruh secara langsung dan signifikan terhadap Indeks Pembangunan Manusia (IPM) di Kabupaten Kutai Barat.

Besarnya pengaruh variabel Pertumbuhan Pengeluaran Pemerintah terhadap Indeks Pembangunan Manusia (IPM) yaitu sebesar 0,260. Pengaruh tersebut tidak signifikan pada signifikansi/probabilitas $0,05(\alpha=5 \%)$ karena 0,0659>0,05, namun pengaruh ini signifikan pada signifikansi/probabilitas $0,10 \quad(\alpha=10$ \%) karena nilai signifikansi/probabilitas hasil perhitungan sebesar $0,059<0,10$. Persamaan Sub Struktur 2 Pengaruh Secara Gabungan (Simultan) Pengaruh variabel eksogen Pertumbuhan
Ekonomi, Pertumbuhan Investasi Swasta, Tenaga Kerja, dan Pertumbuhan Pengeluaran Pemerintah terhadap variabel endogen Kemiskinan adalah sebagai berikut. Besarnya nilai R square (R2) adalah 0,969 dengan signifikansi 0,001. Angka tersebut mempunyai makna bahwa besarnya pengaruh variabel Pertumbuhan Ekonomi, Pertumbuhan Investasi Swasta (PMA), Tenaga Kerja, Pertumbuhan Pengeluaran Pemerintah dan IPM terhadap Kemiskinan secara gabungan (simultan) adalah sebesar 96,9 persen, sedangkan sisanya sebesar 3,1 persen dipengaruhi oleh faktor lain di luar model penelitian. Hasil penelitian sesuai dengan hipotesis karena signifikansi $0,001<0,05(\alpha=5$ $\%$ ), hal ini berarti secara bersama-sama variabel Pertumbuhan Ekonomi, Pertumbuhan Investasi Swasta (PMA), Tenaga Kerja, dan Pertumbuhan Pengeluaran Pemerintah berpengaruh secara langsung dan signifikan terhadap Kemiskinan di Kabupaten Kutai Barat.

Pengaruh Secara Parsial adalah Besarnya pengaruh variabel Pertumbuhan Ekonomi, Pertumbuhan Investasi Swasta (PMA), Tenaga Kerja, dan Pertumbuhan Pengeluaran Pemerintah terhadap Kemiskinan secara 
sendiri-sendiri (parsial) adalah Hubungan antara variabel Pertumbuhan Ekonomi dengan Kemiskinan. Nilai $\mathrm{t}$ tabel pada taraf signifikansi $0,05(\alpha=5$ $\%$ dan Degree of Freedom $(\mathrm{DF}) /$ Derajat Kebebasan $(\mathrm{DK})=\mathrm{n}-3$, atau 10-3 = 7 diperoleh angka $t$ tabel sebesar 2,365.

Hasil SPSS menunjukkan angka $\mathrm{t}$ penelitian sebesar $-9.021>\mathrm{t}$ tabel sebesar 2,365, artinya secara parsial variabel Pertumbuhan Ekonomi berpengaruh secara langsung dan signifikan terhadap Kemiskinan di Kabupaten Kutai Barat. Besarnya pengaruh variabel Pertumbuhan Ekonomi terhadap Kemiskinan dapat dilihat dari nilai koefisien Beta (standardized coefficient) yaitu sebesar -1.199. Pengaruh ini signifikan karena nilai signifikansi/probabilitas hasil perhitungan sebesar $0,001<0,05$.

Hasil penelitian menunjukan bahwa terjadi hubungan yang negative antara keduanya di Kabupaten Kutai Barat. Hubungan yang negative tersebut menunujkan bahwa pertumbuhan ekonomi Kabupaten Kutai Barat belum berkualitas dan terjadinya kesenjangan ekonomi yang semakin lebar. Pertumbuhan Ekonomi tidak dinikmati secara merata tetapi hanya dinikmati kelompok kecil masyarakat.

Hubungan antara variabel Pertumbuhan Investasi Swasta (PMA) dengan Kemiskinan . Hasil SPSS menunjukkan angka t penelitian sebesar 5,699 > t tabel sebesar 2,365, artinya secara parsial variabel Pertumbuhan Investasi Swasta (PMA) berpengaruh secara langsung dan signifikan terhadap Kemiskinan di Kabupaten Kutai Barat. Besarnya pengaruh variabel Pertumbuhan Investasi Swasta (PMA) terhadap Kemiskinan dapat dilihat dari nilai koefisien Beta (standardized coefficient) yaitu sebesar 0,915 . Pengaruh ini signifikan karena nilai signifikansi/probabilitas hasil perhitungan sebesar $0,005<0,05$.

Hubungan antara variabel Tenaga Kerja dengan Kemiskinan. Hasil SPSS menunjukkan angka t penelitian sebesar $2,287<\mathrm{t}$ tabel sebesar 2,365, artinya secara parsial variabel Tenaga Kerja berpengaruh secara langsung namun tidak signifikan terhadap Kemiskinan di Kabupaten Kutai Barat. Besarnya pengaruh variabel Tenaga Kerja terhadap Kemiskinan yaitu sebesar 0,631 . Pengaruh ini tidak signifikan karena nilai signifikansi/probabilitas hasil perhitungan sebesar 0,084 >0,05. 
Hubungan antara variabel Pertumbuhan Pengeluaran Pemerintah dengan Kemiskinan. Hasil SPSS menunjukkan angka t penelitian sebesar $6,862>\mathrm{t}$ tabel sebesar 2,365, artinya secara parsial variabel Pertumbuhan Pengeluaran Pemerintah berpengaruh secara langsung dan signifikan terhadap Kemiskinan di Kabupaten Kutai Barat. Besarnya pengaruh variabel Pertumbuhan Pengeluaran Pemerintah yaitu sebesar 0,736. Pengaruh ini signifikan pada signifikansi/probabilitas $0,05(\alpha=5 \%)$ karena $0,002<0,05$.

Hubungan antara variabel IPM dengan Kemiskinan. Hasil SPSS menunjukkan angka t penelitian sebesar $-6,670>\mathrm{t}$ tabel sebesar 2,365, artinya secara parsial variabel IPM berpengaruh secara langsung dan signifikan terhadap Kemiskinan di Kabupaten Kutai Barat. Besarnya pengaruh variabel IPM yaitu

\section{PENUTUP}

Berdasarkan hasil penelitian dan pembahasan yang telah dilakukan, maka dapat disimpulkan pertumbuhan Ekonomi, Pertumbuhan Investasi Swasta (PMA), Tenaga Kerja, dan Pertumbuhan Pengeluaran Pemerintah secara bersama-sama berpengaruh secara langsung dan signifikan terhadap sebesar -2,004. Pengaruh ini signifikan pada signifikansi/probabilitas $0,05(\alpha=$ $5 \%$ ) karena $0,003<0,05$.

Hasil penelitian menunjukan bahwa terjadi hubungan yang negative antara keduanya, hubungan yang negative tersebut menunjukan bahwa pemerintah Kabupaten Kutai Barat belum maksimal dalam meningkatkan kualitas Sumber Daya Manusia yang tercermin dalam angka IPM dengan komponen-komponen penyusunnya, yaitu : dengan meningkatkan derajat kesehatan masyarakat dan peningkatan pasilitas kesehatan berupa sarana dan tenaga kesehatan, peningkatan pasilitas pendidikan berupa sarana dan tenaga pendidikan, meningkatkan daya beli masyarakat dengan peningkatan pertumbuhan ekonomi yang terdistribusi secara merata..

Indeks Pembangunan Manusia (IPM) di Kabupaten Kutai Barat. Tenaga Kerja berpengaruh dominan terhadap Indeks Pembangunan Manusia (IPM) di Kabupaten Kutai Barat. Peningkatan kesejahteraan masyarakat yang diproksi oleh Indeks Pembangunan Manusia (IPM) terjadi karena dengan penciptaan kesempatan kerja, maka akan terjadi 
peningkatan produktivitas dan secara tidak langsung melalui Indeks pendapatan. Pertumbuhan Ekonomi, Pertumbuhan Investasi Swasta (PMA), Tenaga Kerja, dan Pertumbuhan Pengeluaran Pemerintah serta IPM secara bersama-sama berpengaruh secara langsung dan signifikan terhadap jumlah Penduduk Miskin di Kabupaten Kutai Barat.

IPM berpengaruh dominan terhadap jumlah Penduduk Miskin di Kabupaten Kutai Barat, dengan demikian hasil penelitian ini kurang mendukung hipotesis keempat yang telah dibuat yaitu tenaga kerja berpengaruh dominan terhadap kemiskinan. Semakin tinggi pencapaian angka IPM di Kabupaten Kutai Barat, maka pembangunan manusia yang mencakup komponen kesehatan (angka harapan hidup), pendidikan (angka melek huruf dan rata-rata lama sekolah) dan ekonomi (paritas daya beli) tersebut akan meningkatkan kemampuan untuk memenuhi kebutuhan hidup mereka, sehingga dapat mengangkat derajat kehidupan mereka dari jurang kemiskinan.

Pertumbuhan Ekonomi, Pertumbuhan Investasi Swasta (PMA), Tenaga Kerja, dan Pertumbuhan Pengeluaran Pemerintah berpengaruh Pembangunan Manusia (IPM) terhadap jumlah Penduduk Miskin di Kabupaten Kutai Barat. Berdasarkan kesimpulan, maka dapat disampaikan saran-saran sebagai berikut : Berdasarkan hasil analisis diketahui bahwa variabel eksogen IPM mempunyai pengaruh langsung yang signifikan dan dominan terhadap Kemiskinan di Kabupaten Kutai Barat, oleh karena itu disarankan kepada pemerintah Kabupaten Kutai Barat untuk terus berkonsentrasi pada pembangunan sumber daya manusia yang tercermin dalam angka IPM dengan komponen-komponen penyusunnya, yaitu: dengan meningkatkan derajat kesehatan masyarakat melalui kesadaran masyarakat dan peningkatan fasilitas kesehatan berupa sarana dan tenaga kesehatan; meningkatkan capaian pendidikan masyarakat melalui kesadaran masyarakat dan peningkatan fasilitas pendidikan berupa sarana dan tenaga pendidikan; dan meninhgkatkan daya beli masyarakat dengan peningkatan pertumbuhan ekonomi yang terdistribusi secara merata.

Berdasarkan hasil analisis diketahui bahwa variabel eksogen tenaga kerja mempunyai pengaruh tak 
langsung terbesar terhadap Kemiskinan

di Kabupaten Kutai Barat, oleh karena itu disarankan kepada pemerintah Kabupaten Kutai Barat untuk meningkatkan pencipataan lapangan kerja dengan menitikberatkan perkembangan sektor ekonomi padat karya yang banyak menyerap tenaga kerja. Berdasarkan hasil analisis diketahui bahwa variabel independen Indeks Pembangunan Manusia (IPM) mempunyai pengaruh langsung terbesar terhadap Kemiskinan di Kabupaten Kutai Barat, oleh karena itu disarankan kepada pemerintah Kabupaten Kutai Barat untuk terus meningkatkan

\section{DAFTAR PUSTAKA}

Adisasmita, R. 1989. Beberapa Definisi Ekonomi Regional. Ujung Pandang : Program Pascasarjana Universitas Hasanuddin.

Anonim, 2008. Analisis dan Penghitungan Tingkat Kemiskinan 2008. BPS Indonesia, Jakarta.

Anonim, 2011. Rencana Pembangunan Jangka Menengah Daerah Kabupaten Kutai Barat Tahun 2011-2016. Bappeda Kabupaten Kutai Barat, Sendawar.

Arsyad, Lincolin. 1999. Ekonomi Pembangunan. Edisi keempat, BPFE Yogyakarta. program pendidikan dengan memberikan beasiswa kepada siswa tingkat dasar hingga perguruan tinggi dan dibidang kesehatan pemerintah memberikan layanan pengobatan gratis kepada masyarakat yang kurang mampu. Pemerintah Kabupaten Kutai Barat perlu mencanangkan kembali program pengentasan kemiskinan secara terpadu/terintegrasi antar Satuan Kerja Perangkat Daerah (SKPD), Pihak Swasta, Lembaga Swadaya Masyarakat (LSM), dan Organisasi Masyarakat (Ormas), sebagaimana Gerakan Sendawar Makmur (GSM) yang dulu pernah ada di Kabupaten Kutai Barat.

Boediono, 1981. Teori Pertumbuhan Ekonomi. Edisi pertama. BPFE Yogyakarta.

Djojohadikusumo, S. 1994. Dasar Teori Ekonomi Pertumbuhan dan Ekonomi Pembangunan. LP3ES. Jakarta.

Effendi, Misran, 2009. Pengaruh Investasi dan Tenaga Kerja Terhadap Produk Domestik Regional Bruto (PDRB) Serta Pengaruhnya Terhadap Indeks Pembangunan Manusia di Kabupaten Kutai Barat. Tesis Magister Ilmu Ekonomi Unmul, Samarinda.

Faisal, Sanafiah, 2001. Format-format Penelitian Sosial. PT. RajaGrafindo Persada. Jakarta. 
Irawan dan Suparmoko, M. 1999. Ekonomika Pembangunan dan Perencanaan. BPFE, Yogyakarta.

Jhingan, M.L. 1999. Ekonomi Pembangunan dan Perencanaan, (terjemahan oleh D. Guritno). Edisi pertama. PT. RajaGrafindo Persada, Jakarta.

\section{, 2000. Ekonomi Pembangunan dan Perencanaan, (terjemahan oleh D. Guritno). Jakarta : PT. Raja Grafindo Persada.}

$\begin{array}{lr}\text { Pembangunan } 2008 . & \text { Ekonomi } \\ \text { Perencanaan, (terjemahan } & \text { oleh } \\ \text { D. Guritno). Jakarta } & \text { : PT. Raja } \\ \text { Grafindo Persada. } & \end{array}$

Kuncoro, Mudrajad, 2000. Ekonomi Pembangunan : Teori, Masalah, dan Kebijakan. Fakultas Ekonomi UGM, Yogyakarta.

Pembangunan Daerah :
Reformasi,
Strategi, $\begin{aligned} & \text { Perencanaan, } \\ & \text { Erlangga, Jakarta. }\end{aligned}$
, 2006. Ekonomika Pembangunan : Teori, Masalah, dan Kebijakan. Edisi keempat, UPP STIM YKPN, Yogyakarta.

Kustiawan, Andriawan, 2007. Pengaruh Faktor-Faktor Internal Terhadap Kemiskinan Masyarakat Kelurahan Sidomulyo Kecamatan Samarinda Ilir. Tesis Magister Ilmu Ekonomi Unmul, Samarinda.
Larasati, Endang, 2002. Keuangan Negara. Karunia, Universitas Terbuka. Jakarta.

Levitan, San. A. 1980. Programs in Aid of The Poor far The 1980's : Policy Studies Employment and Welfare No. 1 Fourth Edition. London : The Jhones Hopkins University Press.

Mulyadi S. 2003. Ekonomi Sumber Daya Manusia Dalam Perspektif Pembangunan. PT RajaGrafindo Persada, Jakarta.

2005. Ekonomi Kelautan. Raja Grafindo Persada, Jakarta.

Pass, Cristhoper dan Lowes, Bryan. 1994. Kamus Lengkap Ekonomi. Edisi 2. Terjemahan Tumpal Rumapea dan Posman Haloho. Erlangga. Jakarta.

Ridlo, Muhammad Agung. 1990. Evaluasi Pemukiman Kembali (Resettlement) Masyarakat Miskin (Daerah Studi : permukiman YSS Mangunharjo dan Mayangsari di Kota Semarang). Skripsi tidak diterbitkan. Jurusan Teknik Planologi Universitas islam Bandung.

Riduwan dan Kuncoro Engkos A. 2008. Cara Menggunakan dan Memaknai Analisis Jalur (Path Analysis). Cetakan 2, Alfabeta, Bandung.

Sahadi, 2009. Beberapa Faktor Yang Mempengaruhi Kemiskinan di Provinsi Kalimantan Timur. Tesis Magister Ilmu Ekonomi Unmul, Samarinda. 
Salim, Emil. 1984. Perencanaan Pembangunan dan Pemerataan Pendapatan. Jakarta : Inti Idayu Press.

Sajogyo, 1982. Garis Kemiskinan dan Kebutuhan Minimum Pangan, Dalam Mencari Bentuk Ekonomi Indonesia, Gramedia, Jakarta.

Sarwono, Jonathan,2012. Path Analysis : Teori, Aplikasi, Prosedur Analisis untuk Riset Skripsi, Tesis dan Disertasi (Menggunakan SPSS). Penerbit PT. Elex Media Komputindo. Jakarta.

Sirojuzilam, 2008. Disparitas Ekonomi dan Perencanaan Regional, Ketimpangan Ekonomi Wilayah Barat dan Wilayah Timur Provinsi Sumatera Utara, Pustaka Bangsa Press.

Subli, 2005. Hubungan Kemiskinan dan Faktor-Faktor Penyebabnya pada Masyarakat Desa Kembang Janggut dan Kota Bangun II Kutai Kartanegara. Tesis Magister Ilmu Ekonomi Unmul, Samarinda.

Sukirno, Sadono. 1985. Ekonomi Pembangunan: Proses, Masalah dan Dasar Kebijaksanaan. Bima Grafika, Jakarta.

Suparmoko, 2000. Asas-asas Ilmu Keuangan Negara, Badan Penerbit Fakultas Ekonomi Universitas Gajah Mada. Yogyakarta.

Suparlan, Parsudi. 1984. Kemiskinan di Perkotaan. Sinar Harapan, Jakarta.

Suyanto, Bagong. 1995. Perangkap Kemiskinan : Problem \& Strategi Pengentasannya. Airlangga University Press, Surabaya. 